\title{
8
}
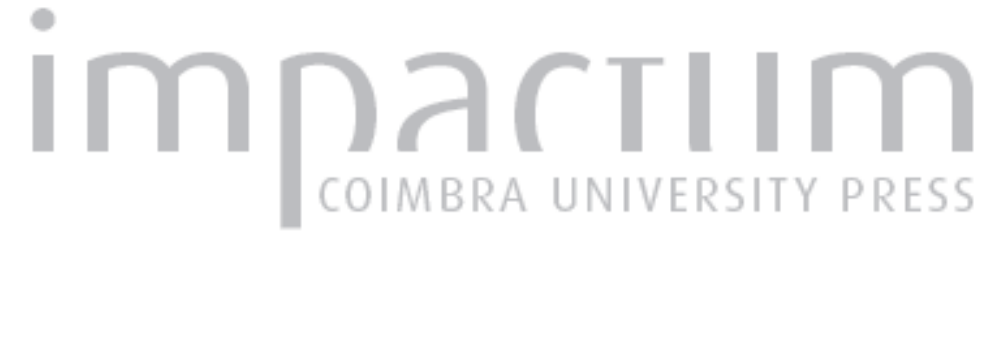

\section{Opportunities missed, warnings ignored: re-discovering the history of drug safety in Great Britain following the thalidomide disaster 1961}

\author{
Autor(es): $\quad$ Anderson, Stuart
}
Publicado por: Centro de Informação Europe Direct de Aveiro; Centro de Estudos Interdisciplinares do Século XX

URL

persistente:

URI:http://hdl.handle.net/10316.2/39348

DOI:

DOI:http://dx.doi.org/10.14195/1647-6336_14_3

\section{Accessed : $\quad$ 26-Apr-2023 11:21:09}

A navegação consulta e descarregamento dos títulos inseridos nas Bibliotecas Digitais UC Digitalis, UC Pombalina e UC Impactum, pressupõem a aceitação plena e sem reservas dos Termos e Condições de Uso destas Bibliotecas Digitais, disponíveis em https://digitalis.uc.pt/pt-pt/termos.

Conforme exposto nos referidos Termos e Condições de Uso, o descarregamento de títulos de acesso restrito requer uma licença válida de autorização devendo o utilizador aceder ao(s) documento(s) a partir de um endereço de IP da instituição detentora da supramencionada licença.

Ao utilizador é apenas permitido o descarregamento para uso pessoal, pelo que o emprego do(s) título(s) descarregado(s) para outro fim, designadamente comercial, carece de autorização do respetivo autor ou editor da obra.

Na medida em que todas as obras da UC Digitalis se encontram protegidas pelo Código do Direito de Autor e Direitos Conexos e demais legislação aplicável, toda a cópia, parcial ou total, deste documento, nos casos em que é legalmente admitida, deverá conter ou fazer-se acompanhar por este aviso.

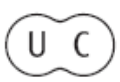


DEBATER

A EUROPA

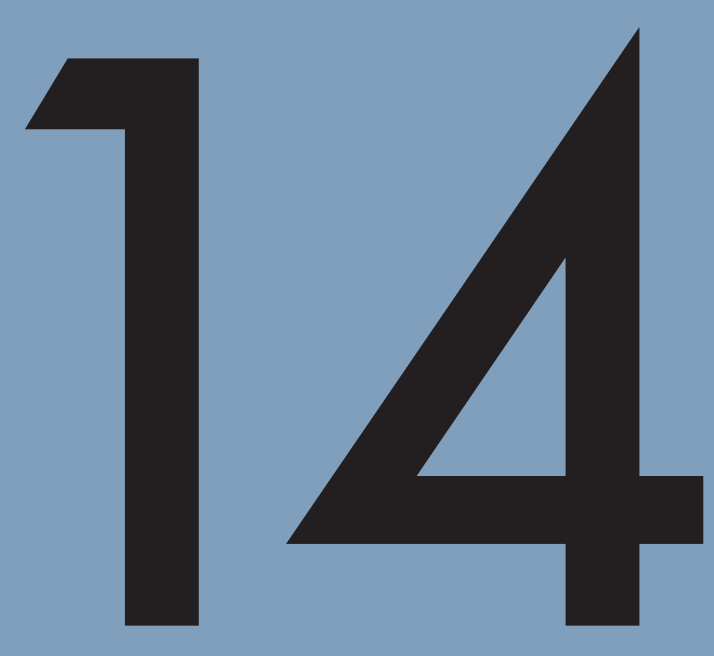

jan-jun 2016

EUROPA, FARMÁCIA, MEDICAMENTOS

EUROPE, PHARMACY, MEDICINES 


\title{
Opportunities Missed, Warnings Ignored: Re-discovering the History of Drug Safety in Great Britain following the Thalidomide Disaster 1961
}

\author{
Stuart Anderson \\ Centre for History in Public Health \\ London School of Hygiene and Tropical Medicine \\ Email: stuart.anderson@1shtm.ac.uk
}

\begin{abstract}
Following the thalidomide disaster1961 many accounts of pre-thalidomide drug safety history appeared. Some identified events which represented missed opportunities or ignored warning signs. This paper reviews three assertions made in these accounts; that an opportunity to introduce a spontaneous reporting system for suspected adverse drug reactions in 1893 was missed; that concerns about dangers of drugs in pregnancy identified in 1904 were ignored; and that a proposal to establish a drug regulatory body made in 1914 was abandoned. The paper concludes that even if all had been acted upon it is unlikely that the thalidomide disaster could have been entirely avoided.
\end{abstract}

Key words: Thalidomide; safety; Britain; history; drugs

\section{Resumo}

Após o desatre da talidomida em 1961 surgiram muitos relatos de histórias de segurança de medicamentos pré-talidomida. Alguns casos identificados representaram oportunidades perdidas ou até mesmo sinais de alerta que foram ignorados. Este trabalho revisita três casos nestas condições: uma oportunidade perdida de introduzir um sistema de notificação de suspeita de reações adversas em 1893; que as preocupações sobre perigos de medicamentos na gravidez, em 1904, foram ignorados; e que uma proposta de criação de um órgão regulador dos medicamentos feita em 1914 foi abandonada. Este estudo conclui ainda que, mesmo que todos os casos anteriores tivessem sido colocados em prática, é pouco provável que o desastre da talidomida pudesse ter sido totalmente evitado.

Palavras-chave: talidomida; segurança; Grã-Bretanha; história; medicamentos 


\section{Opportunities Missed, Warnings Ignored: Re-discovering the History of Drug Safety} in Great Britain following the Thalidomide Disaster 1961

The thalidomide disaster of 1961 was the major watershed in the history of drug safety, not only in Great Britain but throughout the world. Following the tragedy governments everywhere tightened legislation concerned with the regulation of medicines and introduced systems for their approval and monitoring. The tragedy prompted much soul-searching in Parliament, in the industry, and in the medical professions. Developments in its aftermath included rapid expansion of research and teaching in clinical pharmacology; and new drug-focussed disciplines emerged, including pharmacoepidemiology, pharmacoeconomics and pharmacovigilance.

After the initial surge in activity some of those most closely involved in these processes began to reflect on their experiences, and a re-appraisal of the history of drug safety took place. Whilst many of these accounts were highly selective in their choice of earlier incident, some made serious assertions about missed opportunities, about warning signs and about historical precedents. To date these have received limited attention from historians. This paper reviews post-thalidomide observations on the history of drug safety, identifies key missed opportunities and early warnings identified by these authors, and explores the background to them and the reasons effective action was not taken at the time.

\section{Introduction}

The thalidomide disaster came to the attention of the world at the end of 1961 . On 16 December a letter was published in The Lancet from W.G. McBride, headed 'thalidomide and congenital abnormalities. ${ }^{11}$ It soon became apparent that around 10,000 children had been affected. The story of thalidomide has generated a massive literature (see for example, Suffer the Children $1979^{2}$ and Dark Remedy $2001^{3}$ ), and indeed continues to do so (see for example Silent Shock $2015^{4}$ ). The review of medicines regulation which the disaster triggered continues to reverberate around the world. The new order was to see the transformation of medical specialties such as clinical pharmacology, the creation of new regulatory bodies and the growth of new fields of expertise such as regulatory affairs and post-marketing surveillance.

\footnotetext{
${ }^{1}$ McBRIDE, W.G. - 'Thalidomide and congenital abnormalities'. The Lancet. 2 (1961) p. 1358.

${ }^{2}$ SUNDAY TIMES - Suffer the Children: The Story of Thalidomide. London: Andre Deutsch Ltd, 1979.

${ }^{3}$ STEPHENS, T.;BRYNNER R. - Dark Remedy: The Impact of Thalidomide and Its Revival as a Vital Medicine. Cambridge, Mass: Perseus, 2001.

${ }^{4}$ MAGAZANIK, M. - Silent Shock: The Men Behind the Thalidomide Scandal and an Australian Family's Long Road to Justice. Melbourne: Text Publishing Co., 2015.
} 
As these new fields of study became established, attempts were made to provide some historical context to re-interpret what had gone before. Pharmacovigilance, a new discipline defined as 'the science and activities relating to the detection, assessment, understanding and prevention of adverse effects or any other possible drug-related problems, ${ }^{5}$ soon found itself with a history that stretched back at least 150 years and often much longer. These early accounts were usually written by the doctors and pharmacologists most closely connected with post-thalidomide events. They identified a wide range of different features of drug safety from different centuries that they believed indicated the 'dawn of drug safety' or the 'dawn of pharmacovigilance.'

One of the earliest accounts was given by Wade in 1970 in his book on adverse reactions to drugs. ${ }^{6}$ Wade was a former member of the Committee on the Safety of Drugs, set up by the Government in 1963, and a former chair of the Committee on Review of Medicines. He noted that doctors had always appreciated that their treatments were capable of doing harm as well as good. He refers to early scientific attempts to assess the value of therapy at the beginning of the nineteenth century. Possible adverse reactions to Salvarsan were examined at the end of the First World War. Adverse reactions to vaccines and antisera were well understood by the late nineteenth century, and those to drugs became familiar to doctors following introduction of the sulphonamides in the 1930s. For Wade there was a broad but vague awareness that drugs could be harmful, but he identifies no particular lost opportunities or warning signs that had been missed.

Wade's was the first of many such accounts; several dozen have appeared subsequently. Penn's account in 1979 traced the state control of medicines over a 3,000 year period; ${ }^{7}$ like Wade he made no assertions about lost opportunities or missed warning signs. Others identified much later periods as the start of medicines control. Sir Derek Dunlop, first chairman of the Committee on Safety of Drugs in the United Kingdom, addressing the Royal Society in London in 1980, identified 1864 as the year when real control over medicines began, with publication of the British Pharmacopoeia. ${ }^{8}$ But its focus was more on the quality of medicines and the standardisation of formulas than safety. Goldberg, describing the development of drug regulating authorities in 1986, suggested that a meaningful drug regulation system had its origins in the Gin Acts of the eighteenth century. ${ }^{9}$

\footnotetext{
${ }^{5}$ ANONYMOUS. - The Importance of pharmacovigilance: Safety Monitoring of medicinal products. Geneva: World Health Organization, 2002.

${ }^{6}$ WADE, O.L. - 'The Dawn of Concern,' in WADE, O.L. Adverse Reactions to Drugs. London: William Heinemann, 1970. p. 1-10.

${ }^{7}$ PENN, R.G. - 'The State Control of Medicines: The First 3,000 years'. British Journal of Clinical Pharmacology. 8 (1979) p. 293-305.

${ }^{8}$ DUNLOP, D. - 'The Growth of Drug Regulation in the United Kingdom'. Journal of the Royal Society of Medicine. 73 (1980) p. 405-407.

${ }^{9}$ GOLDBERG, A. - 'Development of Drug Regulating Authorities'. British Journal of Clinical Pharmacology. 22 (1986) p. 67S-70S.
} 
Mann's 1988 account was one of the first to suggest that detailed examination of earlier events might identify missed opportunities or warning signs that, if spotted, may have averted or mitigated the thalidomide disaster. He highlighted the significance of the Select Committee on Patent Medicines in 1914, which made a series of recommendations that were not implemented because of the outbreak of war, as a key missed opportunity. Indeed, Mann subsequently claimed that it is not altogether fanciful to look on the children of the thalidomide disaster as late and unwitting victims of World War I. ${ }^{10}$ However, action was taken after the war with regard to biological substances, and Mann declared that 'modern concepts of the control of drug safety in Britain derive from the Therapeutic Substances Act of 1925.'11

Further reflections on the history of drug safety appeared during the 1990s. Cartwright provides a brief history of pharmaceutical regulation in his 1991 book. $^{12}$ In the Harveian Oration to the Royal College of Physicians in 1993 Dollery considered the history of medicines regulation and the relationship between medicine and the so-called 'pharmacological revolution'. ${ }^{13}$ For him publication of the first edition of the London Pharmacopoeia in 1618 was the beginning of an attempt to standardise drug therapy, and at least to take account of drug safety. Rawlings, in his William Withering Lecture to the College the following year, chose to limit historical precedent to William Withering and the foxglove in the late eighteenth century, suggesting instead that the thalidomide disaster of 1961 brought the pre-existing pharmacological paradise to an abrupt halt. ${ }^{14}$

Routledge's account of the history of pharmacovigilance entitled ' 150 years of pharmacovigilance' was published in The Lancet in 1998. He referred to the case of Hannah Greener, a 15-year-old girl who was the first reported case of someone dying whilst being administered chloroform, in 1847. In his paper Routledge refers to the work of The Lancet 'Commission on Chloroform and other Anaesthetics' of 1893, and he links Hannah Greener's death directly to The Lancet's setting up of its Commission. Further, he suggests that as a result of The Lancet's survey 'the forerunner of a spontaneous reporting system for suspected adverse drug reactions (ADRs) was established, at least for a time. ${ }^{15}$ This was an important assertion, suggesting

\footnotetext{
${ }^{10}$ MANN, R.D. - Modern Drug Use: An Enquiry on Historical Principles. Boston: MTP Press, 1989. p. 612.

${ }^{11}$ MANN, R.D. - 'From Mithradatium to Modern medicine: The Management of Drug Safety'. Journal of the Royal Society of Medicine. 81 (1988) p. 727.

12 CARTWRIGHT, A.C. - 'Introduction and History of Pharmaceutical Regulation,' in CARTWRIGHT, A.C.;MATTHEWS, B.R. (eds.) - Pharmaceutical Product Licensing: Requirements for Europe. London: Ellis Horwood, 1991.

${ }^{13}$ DOLLERY, C. - 'Medicine and the pharmacological revolution'. Journal of the Royal College of Physicians of London. 28:1 (1994) p. 5969.

${ }^{14}$ RAWLINGS, M. - 'Pharmacovigilance: paradise lost, regained or postponed?' Journal of the Royal College of Physicians of London. 29 (1995) p. 41-49.

${ }^{15}$ ROUTLEDGE, P. - ‘150 Years of Pharmacovigilance'. The Lancet. 351:9110 (1998) p.1200.
} 
that an important opportunity had been missed, and Routledge's perspective on these events has been quoted in many subsequent accounts of the history of pharmacovigilance. ${ }^{16}$

Surprisingly, given the impact of thalidomide, revisionist accounts of the history of drug safety up to this point generally describe the development of drug regulation in broad terms, with selected incidents indicating earlier concerns with drug safety, but they make no reference to preexisting knowledge about the possible effects of drugs during pregnancy. This omission was rectified in 1998 by Dally, who addressed head-on the question of whether the thalidomide tragedy was preventable. She points out that as early as 1904 Ballantyne, a teratologist and lecturer in antenatal pathology in Edinburgh, had listed 'varieties of foetal morbid states' which included both transmitted diseases and toxicological states. Yet these were firmly ignored by the medical community.

Others too subsequently found early precedents for pharmacovigilance. Like Rawlings, Van Grootheest in his paper entitled 'the dawn of pharmacovigilance', published in 2003, refers to Withering's work on the safety of digitalis in $1785 .{ }^{17} \mathrm{He}$ notes that this work was subsequently recognised as the first systematic paper on a medicinal drug, and Withering drew attention to possible adverse effects of treatment with digitalis. Withering explains the synthesis of digitalis from the foxglove in a standardised way, describes animal tests conducted on turkeys, details the therapeutic effects and symptoms associated with an overdose, and emphasises the importance of proper measurement of the dose. ${ }^{18}$ But the value of systematically cataloguing the actions and uses of other drugs was not appreciated by the medical authorities, and another important opportunity was missed.

The re-discovery of the history of drug safety has continued into the twenty-first century. In 2004 Griffin traced the foundations of medicines regulation back to classical times and the development of products with multiple ingredients such as mithridatium and theraic. ${ }^{19}$ He notes that doubts about the efficacy of these panaceas arose in the mid-eighteenth century, and concerns about the adverse nature of the interactions between the numerous ingredients surfaced in a treatise by Heberden in $1745 .^{20}$ An editorial in 1799 in the Medical and Physical Journal called for the establishment of a public committee of eminent physicians to scrutinise all new products prior to

\footnotetext{
${ }^{16}$ ROUTLEDGE, P. - Idem. p.1200-1201.

${ }^{17}$ VAN GROOTHEEST, K. - 'The dawn of pharmacovigilance: An historical Perspective'. International Journal of Pharmaceutical Medicine. 17:5-6 (2003) p. 195-200.

${ }^{18}$ WITHERING, W. - An Account of the Foxglove and Some of its Medical Uses. London: C.G.J. and J. Robinson, 1785.

${ }^{19}$ GRIFFIN, J.P. - 'Venetian Treacle and the Foundation of Medicines Regulation'. British Journal of Clinical Pharmacology. 58 (2004) p.317-325.

${ }^{20}$ HEBERDEN, W. - 'Antitherica: An Essay on Mithradatium and Theriaca'. Transactions of the Royal College of Physicians. 112 (1745) p. 6.
} 
their being advertised to the public. ${ }^{21}$ This was, it was suggested, another missed opportunity, but Griffin concludes that concepts developed in the history of Mithrodatium form the foundation of modern medicines regulation.

Further revisionist accounts of the history of drug safety have appeared in textbooks relating to the field. Strom and Kimmel in their Textbook of Pharmacoepidemiology give an account largely located in United States developments, and emphasise post-1961 developments. ${ }^{22}$ Rago and Santoso provide a broad European account of drug regulation in their chapter in an international textbook of clinical pharmacology. ${ }^{23}$ Again, this focuses on the post-1961 period. Finally, Stephens in his extensive review of the subject traces concerns about drug safety century by century, from preBiblical times to the twentieth century. ${ }^{24}$ Stephens chronological account ends with the thalidomide disaster, although a brief account of its aftermath and a list of the drugs marketed before 1960 that subsequently were removed from the market is provided.

\section{PRECEDENTS, WARNING SIGNS AND MISSED OPPORTUNITIES}

These various accounts, by distinguished participants in the field, thus usually took a highly selective approach to history, with the search for drug safety incidents being cast widely, both temporally and spacially. Some contain factual errors whilst others make poorly grounded assertions. Few successfully locate events in contemporary historical contexts. These wider issues have since been considered by a number of scholars. Abraham, writing in 1995, points out that the literature on the history of British drug regulation up to that point consisted of little more than a chronological listing of relevant legislation. ${ }^{25} \mathrm{He}$ found that almost all the sources focussed on the use and hazards of medicines, and concluded that the political and economic contexts of regulation remained largely unexplored. He could have added that the social and technological contexts also had been only superficially investigated.

Yet some of these accounts make serious assertions about missed opportunities, about precedents, and about warning signs. The brief review above of this revisionist history identifies a number of events where, the authors claim, sufficient foresight was lacking. Had action been taken

\footnotetext{
${ }^{21}$ ANONYMOUS. - 'Editorial'. Medical and Physical Journal. (1799) p. 1.

${ }^{22}$ STROM, B.L.; KIMMEL, S.E. - 'Historical Background'. Textbook of Pharmacoepidemiology. London: John Wiley \& Sons, 2006. p. 5-9.

${ }^{23}$ RAGO, L.;SANTOSO, B. - 'Drug Regulation: History, Present and Future,' in van BOXTEL, C.J.;SANTOSO, B.; EDWARDS, I.R.(Eds.) - Drug Benefits and Risks: International Textbook of Clinical Pharmacology. Revised Second Edition, Uppsala: IOS Press and Uppsala Monitoring Centre, 2008. p. 65-77.

${ }^{24}$ STEPHENS, M.D.B. - The Dawn of Drug Safety. Winchester, Hants: George Mann Publications, 2010.

25 ABRAHAM, J. - Science, Politics and the Pharmaceutical Industry: Controversy and Bias in Drug Regulation . London: Routledge, 1995. p. 37.
} 
at the time, they suggest, it may have been possible to avoid the thalidomide disaster. The three most significant of these were:

1. The opportunity to introduce a spontaneous reporting system for suspected adverse drug reactions, created in the Report of The Lancet Commission on Chloroform and Other Anaesthetics in 1893 and identified as a key missed opportunity by Routledge in 1998;

2. Concern about the potential dangers of drugs during pregnancy expressed by Ballantyne in 1904, and identified as a key factor by Dally in 1998; and

3. The proposal to establish a formal drug regulatory body made by the Select Committee on Patent Medicines in 1914 and identified as a key issue by Mann in 1988.

But how realistic is it, as asserted by Routledge, to describe The Lancet Commission's work, as described in the 1893 Report, as a forerunner of a spontaneous reporting system, and was any such system ever considered by the Commission itself? Should pre-existing evidence about the dangers of drugs during pregnancy, as reported by Ballantyne in 1904, have been taken as serious warning signs about possible dangers, as asserted by Dally? And to what extent are the recommendations made by the Select Committee on Patent Medicines in 1914 a missed opportunity, as asserted by Mann? These are important suppositions which have not yet been fully explored by historians. The aim of this paper is to examine the background to these three key questions and to consider whether or not the assertions are justified.

\section{The lancet commission on chloroform and other anaesthetics 1893}

Routledge's assertion was that the Report of The Lancet Commission on chloroform and other anaesthetic in 1893 created the forerunner of a spontaneous reporting system for suspected adverse drug reactions, and that the failure of the medical authorities to extend it to other drugs, was a major opportunity missed on two separate occasions; at the time of the Commission Report, and again when the special chloroform committee established by the British Medical Association (BMA) reported in 1901 .

The sequence of events leading up to this stretches back over thirty years, to the discovery of the properties of chloroform. In October 1831 Soubeiran in France prepared chloroform as a new product. Liebig in Germany seems to have discovered it independently in 1832. Dumas worked out its formula in 1834, and its anaesthetic properties in animals were known in England by 1842 and in France by 1847. In 1847 it was used as a general anaesthetic in London hospitals in the form of chloric ether, a solution of chloroform in spirit. Simpson introduced it into general medical practice 
in 1847 , in the face of much opposition from the clergy, the medical profession and members of the public. It was manufactured on a commercial scale in London and Edinburgh.

\section{The Hyderabad Chloroform Commission 1889}

The Lancet Commission on chloroform and other anaesthetics itself had its origins in the earlier Hyderabad chloroform commission of 1889. The link between the two has been described by Thomas, who provides a detailed account of the sequence of events. ${ }^{26}$ Simpson first used chloroform in November 1847, but within eleven weeks Hannah Greener became the first victim of an adverse reaction to chloroform whilst undergoing an operation for an in-growing toenail. Chloroform use took off following John Snow's administration of it to Queen Victoria in 1853, after which it became a respectable drug for use in midwifery. John Snow wrote a book providing a comprehensive account of the actions and uses of chloroform, including all reported deaths resulting from it, in $1858 .{ }^{27}$ The tale of Hannah Greener appeared as the first case in the book.

It was a dispute between the key players in the chloroform story that ultimately led to The Lancet setting up its Commission. Simpson, along with James Syme, the Edinburgh professor of surgery, and later Joseph Lister, maintained that it was safe provided that anaesthesia deepened quickly by administering chloroform liberally by an open method such as on a towel or handkerchief, and that respiration was watched carefully. This became known as the Scottish method. Its basic premise was that, when death occurred, respiratory failure always preceded heart failure. Snow, on the other hand, maintained that an accurate method of delivering a known percentage (up to $4 \%$ ) of choroform vapour in air was essential for its safe use. He showed that cardiac arrest occurred coincidentally with, or even before, respiratory arrest, if the mixture contained 8-10\% chloroform. In fact Francis Sibson, physician at St Mary's Hospital, London, had already shown that, in fatal cases, death was caused by paralysing the heart. ${ }^{28}$

The fact that Sibson and Snow's observations were widely ignored is down to medical doggedness, intransigence, bloody-mindedness and rivalry between London and Edinburgh doctors. The fact is that throughout the rest of the century one or more deaths from chloroform were reported in the journals, deaths that in retrospect were highly preventable. One of the problems however was that most of the deaths occurred in fit patients, in minor procedures using low percentages of chloroform. Clearly there were a number of unanswered questions.

\footnotetext{
${ }^{26}$ THOMAS, K.B. - 'Chloroform: Commissions and Omissions'. Proceedings of the Royal Society of Medicine. 67 (1974) p. 723-730.

${ }^{27}$ SNOW, J. - On Chloroform. London: Churchill, 1858. p. 362.

${ }^{28}$ SIBSON, F. - 'Chloroform'. London Medical Gazette. 7 (1848) p.108.
} 
So began the long series of enquires into the mysteries of chloroform. In fact, between the publication of Snow's book in 1858 and that of The Lancet commission's report in 1893 no fewer than five enquiries into chloroform deaths were carried out. ${ }^{29}$ The first in 1864 , was set up by the Royal Medico-Chirurgical Society in London (now the Royal Society of Medicine). ${ }^{30}$ The Committee found, as Snow had done, that chloroform depresses the action of the heart and can cause death by stopping it beating. It collected references to 123 chloroform deaths, and recommended the use of mixtures, particularly George Harley's mixture of alcohol-chloroformether in the proportions 1:2:3. The recommendation stimulated the production of a variety of anaesthetic devices.

Again, such findings had little impact on what anaesthetists did in practice, and patients continued to die. But in 1875 the section of surgery of the British Medical Association decided to set up their own enquiry. The committee consisted of three Glasgow doctors and became known as the Glasgow Committee. ${ }^{31}$ It began its work in 1877 and reported in 1880. It found that chloroform had a disastrous action on both the heart and respiratory centre of rabbits, and that ether was superior to chloroform in almost all respects. They recommended the use of dichloroethane instead, as it occupied a position between ether and chloroform. The general response to the report of the Glasgow Committee by the medical community was, as in 1864 , to take no notice; the 'etherists' continued to use ether and the 'chloroformists' continued to use chloroform. The fatalities continued; 120 deaths from chloroform were reported in the British Medical Journal between 1870 and 1880, and about 250 in the ten years between 1881 and 1890. It was nearly ten years after publication of the Glasgow Committee report before the next initiative was taken; this time it came from outside the United Kingdom.

On 23 February 1889 The Lancet quoted the words of Surgeon-Major Lawrie of the Bengal Medical Service in India, who was also Principal of the Hyderabad Medical School. Lawrie was an Edinburgh graduate, a student of Syme and Lister, and a forceful and persistent character. He was interested in the actions of chloroform and persuaded the local ruler, the Nizam, to appoint a commission to carry out experiments. This later became known as the First Hyderabad Commission. ${ }^{32}$ Chloroform was used to anaesthetise 128 full-grown pariah dogs, and it was found that 'in no case did the heart become dangerously affected by chloroform until after the breathing had stopped.' Lawrie went on to state that 'in his 40 or 50,000 administrations he had never seen the

\footnotetext{
${ }^{29}$ THOMAS, K.B. - 'Chloroform: Commissions and Omissions'. Proceedings of the Royal Society of Medicine. 67 1974 p. $723-730$.

${ }^{30}$ ANONYMOUS. - 'Royal Medico-Chirurgical Society Chloroform Committee'. Medico-Chirurgical Transactions. 47 (1864) 323.

${ }^{31}$ WELLS, T.S. - 'Glasgow Committee on Anaesthetics'. British Medical Journal. 2 (1877) 224.

32 MASSON, A.H.B.;WILSON, J.;HOVELL, B.C. - 'The First Hyderabad Commission'. British Journal of Anaesthesia. 41 (1969) 1002.
} 
heart injuriously or dangerously affected by chloroform.' Further he declared that deaths would continue to occur until the London schools ignored the heart in chloroform administration, or confined themselves to other anaesthetics.

It was The Lancet's response to this assertion that led directly to its Commission on chloroform. It declared: 'Mr Lawrie, as a discipline of Simpson and Syme, arrives at conclusions consonant with the teaching of those great clinicians, but utterly at variance with the experience alike of experiment and practice as carried out in Europe.' The journal also compared Lawrie's work with the findings of the 1864 and Glasgow Committees and the 'painstaking and careful experiments of Snow, Claude Bernard, McKendrick and others. ${ }^{33}$

The public exchange between The Lancet and Lawrie continued for several months, but took a new turn on 18 August 1889. Lawrie announced that he had secured $£ 1,000$ to enable The Lancet to send out a representative to repeat the experiments of the First Hyderabad Chloroform Commission. The Lancet chose T. Lauder Brunton of St Bartholomew's Hospital, London, a pharmacologist with an international reputation. Brunton started work immediately, and sent his first telegram from Hyderabad which was published in The Lancet on 7 December 1889. It read: 'Four hundred and ninety dogs, horses, monkeys, goats, cats and rabbits used. One hundred and ninety with manometer. All records photographed. Numerous observations on every individual animal. Results most instructive. Danger from chloroform is asphysia or overdose; none whatever heart direct.'

Following this catalogue of slaughter, Brunton revised his views. The full report of the Second Hyderabad Chloroform Commission ran to over 400 pages, and was published in full in The Lancet over many issues in $1890 .{ }^{34}$ It completely supported Lawrie's position, which had been that of Syme and Lister before him, but opposed that previously demonstrated by that of Snow and Sibson.

\section{The Report of The Lancet Commission on Chloroform 1893}

The conclusion reached by the Second Hyderabad Chloroform Commission was that 'the theory which has hitherto been accepted is that the danger in chloroform administration consists in the slowing or stoppage of the heart by vagus inhibition. This is now shown to be absolutely incorrect.' This did not satisfy The Lancet. They were at variance with a great deal of other experimental evidence. In 1893 therefore, The Lancet asked Dudley Buxton, a doctor with extensive experience of anaesthesia at University College Hospital, London, to lead a Commission to investigate the clinical position. So began The Lancet's 1893 Commission on chloroform.

\footnotetext{
${ }^{33}$ ANONYMOUS. - 'Editorial'. The Lancet. 1(394) 1889 p. 438.

${ }^{34}$ ANONYMOUS. - 'Second Hyderabad Chloroform Commission'. The Lancet. 1 (1890) p. 149, 421, 486, $1140,1369$.
} 
The method of data collection was to send a form to all members of the profession. The form asked a wide range of questions, from 'what anaesthetic do you normally employ and how?' and 'what class of case?' to 'can you give particulars of any deaths?' and 'did heart or respiration stop first?' In addition a larger form was sent to every hospital in the United Kingdom with more than ten beds, and also to 'all the larger hospitals of the Continent, as well as to India, America and the Colonies'. This asked rather different questions, such as 'number of times anaesthetics given during the past ten years?' 'how many deaths under which anaesthetic?' and describe the 'institution's experience of relative dangers of anaesthetics.'

The Commission found that the responses produced referred mainly to recent cases, and so they supplemented the data by a careful search for particulars concerning dangerous and fatal cases under anaesthetics reported in the current professional and lay papers.' They were keen to obtain 'a continuous series of cases from 1847' (the date of the first employment of chloroform as an anaesthetic), and included data from John Snow's 1858 report 'on anaesthetics' and those collected by the Royal Medical and Chirurgical Society and published in their Transactions in 1864. The Commissioner also examined the case books of some of the larger hospitals.

The report itself divided anaesthetics into four groups; chloroform, ether, mixtures of anaesthetics, and less common anaesthetics, such as ethyl bromide and nitrous oxide. ${ }^{35}$ The cases were divided into three types; deaths under and apparently due to an anaesthetic; deaths under and remotely due to an anaesthetic; and untoward cases-those in which some mishap occurred which was not followed by fatal results, but which was directly or remotely due to the anaesthetics employed.' The total number of deaths reported was worryingly high. Most deaths, some 506 cases, resulted from heart failure and respiratory cessation.

\section{The British Medical Association's Special Chloroform Committee 1901}

The Lancet Commission's findings completely vindicated Snow's and Sibson's position, that chloroform caused death through its impact on the heart rather than on respiration. Clinical data demonstrated that results obtained in experiments carried out in rabbits, cats and dogs could not readily be translated to human subjects.

Again, little action was taken in the light of the Commission's findings. With so much attention devoted to chloroform it might be hoped that the number of deaths resulting from it might drop. In fact, they continued to rise, from over 40 a year in the early 1890s to over 60 a year in the mid-

\footnotetext{
${ }^{35}$ ANONYMOUS. - 'Report of The Lancet Commission Appointed to Investigate the Subject of the Administration of Chloroform and Other Anaesthetics from a Clinical Perspective'. The Lancet. 18 March (1893) p. 629-638.
} 
1890s. ${ }^{36}$ The response was yet more enquiries; the British Medical Association set up a Special Chloroform Committee in $1901 .^{37}$ Its purpose was to find a safe dosage regimen and the means of delivering it. The committee sat for nine years, eventually producing a long and comprehensive report in 1910, running to 25 pages of the British Medical Journal. It recommended that chloroform should be administered using regulating inhalers providing a constant mixture at a maximum strength of $2 \%$. Despite the new recommendation deaths from chloroform continued. Physicians simply carried on in the same old way. And the British Medical Association saw no reason to look at any other drug. The next key development came from across the Atlantic; the American Medical Association's Committee on Anaesthesia in 1910 stated that 'the use of chloroform for major operations is unjustifiable.' Probably a few more doctors stopped using it, and attitudes slowly changed as the older generation gave way to the new. Gradually chloroform passed from use.

The time and effort devoted to chloroform and other anaesthetics was thus enormous. Yet the medical authorities were totally focussed on these agents, despite the appearance of increasing numbers of potent medicines such as aspirin, phenacetin, barbitone and cocaine. Any opportunity to take a wider view of drug safety was completely overlooked. The Lancet Commission was a single response to a single issue. There was never any discussion about extending the review to other drugs, or indeed of continuing it with regard to anaesthetics. The review was retrospective rather than prospective, global in reach rather than population-specific, and focused on clinical effect rather than pharmacological action. For an opportunity to be missed it first needed to be recognised as such. At the time, the data collected was seen simply as a means of resolving a single question, rather than as a prototype for a spontaneous reporting system for suspected adverse drug reactions.

\section{Concern with the effects of drugs on the unborn 1904}

Since 1961 a great deal has been written about what was known about the passage of drugs across the placental barrier before the thalidomide disaster. ${ }^{38}$ It is however an area where regulation played no part whatsoever before the Medicines Act of 1968. But the placenta had been the object of interest and study since earliest times. Today we know that placental villi are washed with maternal blood, and that some substances in the mother's blood can find their way into the foetus's blood. But other medical beliefs about the subject were firmly held before thalidomide. It was thought that the two circulations did not inter-mingle, and that there was a physical barrier between

\footnotetext{
${ }^{36}$ WALLER, A.D. - Physiology, the Servant of Medicine. The Hitchcock Lecture 1909, London: University of London Press, 1910. p. 103.

${ }^{37}$ ANONYMOUS. - 'Special Chloroform Committee'. British Medical Journal Supplement. 56 (1910) p. 47-72.

${ }^{38}$ PERSAUD, T.V.N. - Problems of Birth Defects: from Hippocrates to Thalidomide and After-Original Papers with Commentaries. Lancaster: MTP Press, 1977. p. 196.
} 
the two. Indeed, as one contributor to The Lancet noted, medical students in the mid-twentieth century were taught that the human placenta gave perfect protection to the foetus and was impervious to toxic substances, except in such large doses that they killed the mother. ${ }^{39}$

Yet a lot was already known even before the start of the twentieth century about the placental passage of drugs. Indeed even the Greek physician Hippocrates was writing some 2,500 years ago that 'drugs may be administered to pregnant women from the fourth to the seventh month of gestation.' Studies of the permeability of the placenta to pathological agents were taking place in the mid-eighteenth century. Watson wrote in 1749 that 'the foetus does not always partake of the infection of its mother or the mother from the foetus....the child before its birth, though closely defended from external air, is not secure from the various infections, though its mother has had distemper before. ${ }^{40}$ Similar observations about microbiological passage were made over the following years. In 1839 Tellegen inoculated a pregnant woman with cow pox, and noted that three weeks later she had a full-term child with four tiny pocks, with more appearing over the next few days. This was clear evidence that the virus was able to pass through the foetal capillaries. In 1882 Spitz and Albrecht showed that small pox was able to pass from mother to foetus. In the same year Behm carried out intra-uterine vaccination in 38 pregnant women.

There was also a long history of studying the passage of inorganic materials from mother to foetus. In 1817 Mayer demonstrated the transfer of potassium ferrocyanide from one to the other. In 1858 Schauenstein and Spaeth used potassium iodide to treat women suffering from syphilis, and were able to detect iodide in the meconium and amniotic fluid. In 1859 Albers demonstrated the passage of cyanide from the mother to the foetus, confirming the earlier work of Meyer. The passage of iodide was confirmed by Runge in 1877. Other studies confirmed the passage of phosphorus from mother to foetus in women who were in the habit of sucking match heads. The later decades of the nineteenth century saw many experiments on animals, including rabbits and guinea pigs, although the results were often inconclusive. ${ }^{41}$

There were also studies of the transfer of organic materials and drugs, although again mainly using animals. As early as 1817 Magendie reported that camphor given to pregnant dogs eventually reached the foetus. Carbon monoxide was studied by a number of workers, although Preyer was unable to detect traces of carboxyhaemoglobin in foetal blood even when the concentration of that of the mother was high. A number of studies involved injecting dyes and seeing if they appeared in the foetal blood. As early as 1817 Mayer gave repeated doses of indigo and saffron to pregnant rabbits; he found a green fluid in the stomach and intestine of each foetus. In 1867 Jassinsky used

\footnotetext{
${ }^{39}$ DALLY, A. - 'Thalidomide: Was the Tragedy Preventable?' The Lancet. 351 (1998) p. 1197.

${ }^{40}$ JACK, B.; SMITH, W. - 'Placental Passage of Drugs: Pre-20 ${ }^{\text {th }}$ Century Evidence'. Pharmaceutical Historian. 16 (1986) p.6-8.

${ }^{41}$ JACK, B.; SMITH, W. Idem. p. 7.
} 
indigo-carmine, but found no trace in foetal blood. In $1878 \mathrm{Zuntz}$ and Wiener injected pregnant rabbits with methylene blue, and again detected it in the amniotic fluid but not the foetus itself. ${ }^{42}$

The earliest drug studies date from around the middle of the nineteenth century. Preyer administered atropine to a pregnant guinea pig. After 15 minutes he removed the foetus and found that its pupils were dilated. In 1874 Zweifel studied the passage of chloroform from human mothers to their foetuses; he demonstrated the abundant and rapid transfer of chloroform from the mother's blood to that of the umbilical cord. Later studies in animals involved the use of curare, strychnine, veratrine and ergotrine, but again produced contradictory results. The first unequivocal proof of the placental passage of a drug by chemical means is however credited to Eduard Marquis, who reported the passage of morphine from mother to foetus in a pregnant cat in $1896 .{ }^{43}$

So, with this very substantial body of knowledge about the transfer of materials from mother to foetus, why had lessons not been learnt? Inevitably, it was a complex picture, with conflicting scientific evidence and intransigent medical beliefs both playing a part. There were large interspecies variations; and even when passage from mother to foetus was proved there was little evidence of permanent damage to the foetus. Although large numbers of substances were shown to cross the placental barrier the effects on the foetus were usually seen as more pharmacological than toxicological; chloroform and morphine usually soon cleared the bloodstream leaving the foetus without permanent damage. There were exceptions; the effect on the foetus of mothers drinking alcohol were well known by the early nineteenth century. In 1834 there had even been a House of Commons Select Committee looking at the problem; it noted that children of alcoholic mothers presented a starved, shrivelled and imperfect appearance. ${ }^{44}$

Studies of the placental passage of materials continued throughout the twentieth century. In 1941 the Australian obstetrician N.M. Gregg showed that maternal rubella could damage a growing foetus. ${ }^{45}$ But unlike most of the other evidence, this became part of the medical profession's collective wisdom, and vaccination was introduced. Again, the evidence of harm was not always clear cut. Two years later, in 1943, an attempt to induce cretinism in animals failed; instead it led to foetal skeletal deformities that were later shown to be the result of riboflavin deficiency. Further evidence that foetuses could be damaged by external influences such as maternal malnutrition was provided by Warkany. ${ }^{46}$ But these results were seen as extreme and irrelevant rather than as a warning deserving of further investigation.

\footnotetext{
${ }^{42}$ JACK, B.; SMITH, W. Idem. p. 7.

${ }^{43}$ JACK, D.B.; LAUGHER, S.J. - 'The Earliest Demonstration of the Placental Passage of Morphine?' Pharmaceutical Historian. 12 (1982) p.7-8.

${ }^{44}$ ANONYMOUS. - Select Committee on Alcohol. London: House of Commons, 1834.

45 GREGG, N.M. - 'Congenital Cataract following German Measles in the Mother'. Transactions of the Ophthalmological Society of Australia. 3 (1941) p. 35-46.

${ }^{46}$ WARKANY, J. - 'Congenital Malformations Induced by Maternal Nutritional Deficiency'. Journal of Paediatrics. 25 (1944) p. 476-80.
} 
Why were some findings ignored whilst others, such as rubella, were acted upon? The rubella findings came from other doctors, in maternity units, rather than from laboratories. The findings were clear and easy to understand, and were soon confirmed by further studies from around the world. Those engaged in the field of teratology, which has its origins in France in the eighteenth century, were seen as marginalised and irrelevant. J. W. Ballentyne, one of the first British teratologists and a lecturer in antenatal pathology in Edinburgh, in 1904 carried out a classification of foetal morbid states that included transmitted diseases and toxicological states such as leadpoisoning, alcoholism and morphine-poisoning. ${ }^{47}$ But few doctors took any notice. It was not considered relevant for mammals until the 1930s. Even in 1937, the diagnosis of foetal abnormalities was discussed, but not their causes.

So by the 1950s the impact of drugs on the unborn was not high on the agenda. Yet the 1950s saw an explosion in the number of new chemical entities entering medicine, which Watt subsequently described as the 'pharmacological revolution'. ${ }^{48}$ Between 1952 and 1960 alone nearly 1,000 new medicinal products came onto the British market, of which some 118 were entirely new substances. ${ }^{49}$ Prior to the thalidomide disaster drug regulation in Great Britain was completely unfit for the task. Yet it would be untrue to say that no tests were done on pregnant animals before the launch of any new drug. Some manufacturers did indeed carry out such tests. However, doing so was an entirely voluntary activity.

\section{The select committee on patent medicines 1914}

The medical profession was, however, taking much more of an interest in the exploitation of the public by the manufacturers of proprietary medicines in the late nineteenth and early twentieth centuries. ${ }^{50}$ The British Medical Association began a campaign against them, and undertook the analysis of the contents of a range of patent medicines, the cost of the actual ingredients used, and the claims made for them. They published the results in a popular book Secret Remedies: What they Cost and What they Contain in $1909 .{ }^{51}$ The success of the exercise prompted analysis of further patent medicines and publication a second volume, More Secret Remedies: What they Cost and What they Contain in $1912 .^{52}$

\footnotetext{
${ }^{47}$ BALLANTYNE, J.W. - Essentials of Obstetrics. Edinburgh: Green, 1904. p.101.

${ }^{48}$ WATT, J.A. - 'The Pharmacological Revolution'. Rhode Island Medical Journal. 42 (1959) p. 168-71.

${ }^{49}$ HODGES, M.;APPELBE, G.E. - 'Control of the Safety of Drugs 1868-1968, Part1'. The Pharmaceutical Journal. 239 (1987) 121.

${ }^{50}$ HOLLOWAY, S.W.F. - Royal Pharmaceutical Society of Great Britain 1841 to 1991: A Political and Social History. London: The Pharmaceutical Press, 1991. p. 249.

${ }^{51}$ ANONYMOUS. - Secret Remedies: What They Cost and What They Contain. London: British Medical Association, 1909.

52 ANONYMOUS. - More Secret Remedies: What They Cost and What They Contain. London: British Medical Association, 1912.
} 
The books prompted debate about what action needed to be taken to curb the excesses of the patent medicines trade. The editor of the British Medical Journal, Ernest Hart, was also chairman of the BMA's Parliamentary Bills Committee, and was in a strong position to lobby for any legislation that might be required. The House of Commons eventually agreed that a Select Committee should be appointed to look at the issues and to make recommendations. In fact its terms of reference extended beyond just patent medicines. The Committee was appointed 'to consider and inquire into the question of the sale of patent and proprietary medicines and medical preparations and appliances, and advertisements relating thereto...' The Committee took its work very seriously. Its meetings extended over three sessions of Parliament, and involved 33 sittings in public with 42 witnesses being called to answer 14,000 questions. ${ }^{53}$

The Committee were scathing in their findings. They found that while in the United States the sale of medical preparations was regulated by the Food and Drugs Act of 1906, with an amending Act passed in 1912, the situation in Great Britain regarding the sale and advertising of patent and proprietary medicines was completely unsatisfactory. They noted that:

For all practical purposes British law is powerless to prevent any person from procuring any drug, or making any mixture, whether potent or without any therapeutical activity whatever (so long as it does not contain a scheduled poison) advertising it in any decent terms as a cure for any disease or ailment, recommending it by bogus testimonials and the invented opinions and facsimile signatures of fictitious physicians, and selling it under any name he chooses, on the payment of a small stamp duty, for any price he can persuade a credulous public to pay. ${ }^{54}$

The Committee made a total of twelve wide-ranging recommendations, the most farreaching of which were the following:

56 (1). That the administration of the law governing the advertisement and sale of patent, secret and proprietary medicines and appliances by coordinated and combined under the authority of one Department of State.

56 (2). That this administration be part of the functions of the Ministry of Public Health when such a Department is created, and that in the meantime it be undertaken by the Local Government Board.

56 (3). That a competent officer be appointed to this Department, with the duty of advising the Minister at the head of the Department concerned regarding the enforcement of the law in respect of these remedies.

\footnotetext{
${ }^{53}$ MANN, R.D. - Modern Drug Use: An Enquiry on Historical Principles. Lancaster: MTP Press, 1984. p.613.

${ }^{54}$ ANONYMOUS. - Report from the Select Committee on Patent Medicines, Together with the Proceedings of the Committee, Minutes of Evidence, and Appendices. London: Her Majesty's Stationery Office, 1914.
} 
56 (5). That there be established at the Department concerned a register of manufacturers, proprietors and importers of patent, secret and proprietary remedies, and that every such person be required to apply for a certificate of registration.

56 (6). That an exact and complete statement of the ingredients ... and a full statement of the therapeutic claims made or to be made... be furnished to this Department.

56 (7). That a special Court or Commission be constituted with power to permit or prohibit...the sale and advertisement of any patent, secret or proprietary remedy...

56 (12). That inspectors be placed at the disposal of the Department to examine advertisements and observe the sale of proprietary remedies and appliances.

In addition, the Committee made a number of proposals for additional legislation. These included the prohibition of advertisements of medicines claiming to provide cures for a wide range of conditions including cancer, diabetes, epilepsy and deafness. Also prohibited were advertisements for remedies claiming to provide cures for diseases arising from sexual intercourse, referring to sexual weakness, or suggesting that a medicine might be an abortifacient. Furthermore, it should be a breach of the law to change the composition of a remedy without informing the Department of the proposed change. Other proposals related to giving any remedy a false trade description, making use of fictitious testimonials, and publishing a recommendation from a medical practitioner unless the full name, qualifications and address were given.

If they had been implemented in full the recommendations resulting from the Select Committee on Patent Medicines would undoubtedly have transformed medicines regulation and drugs safety in Great Britain. Unfortunately the Report 'was Ordered by the House of Commons to be Printed' on $4^{\text {th }}$ August 1914, the very day that Britain declared war on Germany leading to its entry into the First World War. The normal business of the House of Commons, including consideration of the recommendations of the Reports of its Select Committees, was suspended for the duration of the war. But for its outbreak, a Medicines Commission and formal drug regulatory body might well have existed in Britain before the emergence of large numbers of new therapeutic agents. $^{55}$

In the event legislation appeared piecemeal and incrementally. Specific claims about therapeutic effects were controlled by the Venereal Diseases Act of 1917 and later the Cancer Act 1939. A need to fulfil international agreements on narcotics originally made at The Hague Convention in 1912 resulted in the Dangerous Drugs Act of $1920 .^{56}$ And the requirement for biological standardisation for newly discovered biological substances, the purity and potency of

\footnotetext{
${ }^{55}$ MANN, R.D. - 'From Mithradatium to Modern medicine: The management of drug safety'. Journal of the Royal Society of Medicine. 81 (1988) p. 727.

56 ANDERSON, S.C.;BERRIDGE, V.S. - 'Opium in Twentieth Century Britain: Pharmacists, Regulation and the People'. Addiction. 95:1 (2000) p. 23-36.
} 
which could not be assessed by chemical means, led to the passing of the Therapeutic Substances Act in 1925. Some of the recommendations of the Select Committee had to wait over fifty years to be implemented, in the Medicines Act of 1968, and some were never taken up. ${ }^{57}$

\section{Discussion}

Consideration of the circumstances surrounding the three key events examined here provides a basis for assessing the validity of the claims made by Routledge, Dally and Mann as to whether or not important opportunities were missed or warning signs ignored, which could potentially have helped to anticipate, ameliorate or possibly even avoid a disaster on the scale of thalidomide. The assertions made in the light of the evidence presented can now be reviewed.

\section{a) The Lancet Commission and spontaneous reporting systems}

Does analysis of the evidence support or refute Routledge's assertion that The Lancet Commission on Chloroform and Other Anaesthetics 1893, which had its origins in the death of Hannah Greener in 1847, and specifically the detailed survey the Commission carried out in 1893 as part of its work, effectively established the forerunner of a spontaneous reporting system for suspected adverse drug reactions? There was certainly a large number of potent drugs available by that time. Penn points out that during the second half of the nineteenth century 'there was a rapid increase in the number of drugs available, both due to chemical innovation and to exploration and discovery worldwide. The preparation and standardisation of such drugs as morphine, quinine, atropine and synthetic chemicals such as carbolic acid, salicylic acid or phenacetin was certainly not a suitable task for the small pharmacist.' Increasingly they were produced by the pharmaceutical industry.

Phenacetin was one of a series of potent analgesics that had been discovered during the second half of the nineteenth century. Gerhardt had discovered acetanilide (antifebrine) in 1853. In 1883 Knorr synthesised discovered antipyrine (phenazone), an early representative of these synthetic pain-relief and anti-inflammatory substances. It was followed by the less toxic phenacetin (acetophenetidin) in 1887, and by amidopyrine (pyrimadon) in $1896 .^{58}$ But already there were signs that more potent drugs might have dangerous side effects. Amidopyrine was three times more effective than phenazone, but was soon found to be a cause of agranulocytosis, which is fatal if untreated.

Nor were the analgesics the only group where rapid development took place. Narcotics underwent a revolution. The molecular formula of narcotine was established in 1836, of morphine

\footnotetext{
${ }^{57}$ PENN, R.G. - 'The State Control of Medicines: The First 3,000 years'. British Journal of Clinical Pharmacology. 8 (1979) p. 302.

${ }^{58}$ GRIER, J. - A History of Pharmacy. London: The Pharmaceutical Press, 1937. p. 200.
} 
in 1838, of codeine in1838, of papaverine in 1850 and thebaine in 1870. All quickly entered medical practice. Morphine started to displace opium from $1855 .^{59}$ The same was true of other drugs originally obtained from natural sources; quinine and cinchonine were first used in place of cinchona bark for fever as early as 1821 by Homel. ${ }^{60}$ Many other potent chemical entities were known and in use by 1893 . So by the time The Lancet Commission report appeared there were already a large number of other potent drugs available, and the significance of adverse drug reactions was well-recognised.

Indeed, recognition of the effect of adverse drug reactions was well-established well before The Lancet Commission report. The first book on adverse drug reactions, 'Die Nebenwirkungen der Arzneimittel' was edited by Louis Lewin in $1881 .^{61}$ In 1909 , a book on the harmful effects of acetanilide, antipyrine, and phenacetin edited by Lyman Frederick Kebler was published in the USA. ${ }^{62}$ A second German work on side effects by Otto Seifert was published in $1915 .{ }^{63}$ These three books were published in a time when the first synthetic active ingredients entered the market as drugs on an industrial scale. A recent study has compared Lewin's, Seifert's and Kebler's knowledge on the side effects of phenazone with the side effects of the drug as known today. It demonstrates that the information on adverse reactions available to doctors at the end of the nineteenth century was extensive and accurate, although it was still very much a developing field. ${ }^{64}$

\section{b) Drugs in pregnancy 1904}

It is clear also that warning signs were clear well before disaster struck in 1961. Indeed, just a year before, in 1960, Baker had provided a comprehensive account of the effects of drugs on the foetus $^{65}$. But the situation was poorly understood. Part of the problem was that there is enormous variability between species, such that conclusions drawn from observations in one species could not be generalised to other species; another was than even severe abnormalities were seen, all be it rarely, in the absence of external factors such as environmental influences or drugs. In the case of thalidomide, the condition described as phocomelia in which there is defective development of the long bones of the limbs with victims being left with rudimentary hands or feet, was very rare but

\footnotetext{
${ }^{59}$ GRIER, J. Idem. 1937. p. 93.

${ }^{60}$ GRIER, J. Idem. 1937. p. 103.

${ }^{61}$ LEWIN, L. - Die Nebenwirkungen der Arzneimittel. Berlin: Germany, 1881.

${ }^{62}$ KEBLER, L.F. - The Harmful Effects of Acetanilide, Antipyrine, and Phenacetin. Washington: USA, 1909.

${ }^{63}$ SEIFERT, O. - Die Nebenwirkungen der Modernen Arzneimittel. 2 vBde, Wurzburg: Germany, 1915.

${ }^{64}$ SCHNEIDER A, HELMSTÄDTER A. - Adverse Drug Reactions of Phenazone; Knowledge from Books around 1900 compared to Today's Summary of Product Characteristics. Berlin 2011. Available at http://www.histpharm.org/40ishpBerlin/P42P.pdf. Accessed 27 October 2015.

${ }^{65}$ BAKER, J.M. - 'The effects of Drugs on the Foetus'. Pharmacology Reviews. 12 (1960) p. 37-90.
} 
not unknown in West Germany before 1960. No cases had been reported during the ten years between 1949 and 1959, but in 1961 alone there were 477 cases. ${ }^{66}$

But all these drugs are products of the post-thalidomide era. So if it had not been thalidomide it would have been some other drug which caused the disaster that thalidomide did. And the methods used to test for teratogenicity have all been developed since 1961. Even if there had been recognition of a potential problem it is unlikely that it could have been detected using the methodologies that were available at the time. ${ }^{67}$

Despite Ballantyne's earlier observations the teratological work on mammalian foetuses did not begin seriously until the 1930 s. $^{6}$ Dally suggests that the delay may have been due to the pervasive belief in the impermeability of the human placenta. She also draws attention to the fact that those working on the subject were not part of the medical mainstream. They published their work in specialists journals with a limited readership, their results did not fit current beliefs, and their articles were not reported in general medical journals such as The Lancet and the British Medical Journal. All this meant that current views about the nature of the relationship between teh blood supplies of foetus and mother were not challenged.

Another important factor was that drug-induced teratogenic effects (the capacity of an agent to cause deformities in a foetus) are surprisingly uncommon in humans. By 1976 more than 2,000 chemicals had been tested for such effects in laboratory animals; about one third had been shown to be teratogenic in one or more animal species. ${ }^{69}$ Yet very few drugs turn out to be teratogenic in man. As well as thalidomide those that have been shown to be predictably teratogenic include aminopterin, methotrexate, hormones including androgens and progestogens, and the anti-thyroid drugs. ${ }^{70}$ Other high risk drugs are the alkylating agents, antimetabolites and cytotoxic agents used in cancer treatment which have an effect on cell growth.

\section{c) Select Committee on Patent Medicines 1914}

The British Medical Association's campaign against patent medicines, the growing awareness about possible adverse reactions to new drugs, and action being taken elsewhere, most notably the United States, led to recognition amongst some policy makers in Great Britain that legislative action might be necessary. In fact by 1914 the need for a more systematic approach to the testing of drugs and the monitoring of their safety was recognised by some in the medical

\footnotetext{
${ }^{66}$ PENN, R.G. - 'The State Control of Medicines: The First 3,000 years'. British Journal of Clinical Pharmacology. 8 (1979) p. 303.

${ }^{67}$ PENN, R.G. - 'The State Control of Medicines: The First 3,000 years'. British Journal of Clinical Pharmacology. 8 (1979) p. 303.

${ }^{68}$ DALLY, A. - 'Thalidomide: Was the Tragedy Preventable?' The Lancet. 351 (1998) p. 1199.

${ }^{69}$ SCHARDEIN, J.L. - Drugs as Teratogens. Cleveland: CRC Press, 1976.

${ }^{70}$ MANN, R.D. - Modern Drug Use: An Enquiry on Historical Principles. Lancaster: MTP Press, 1984. p. 611.
} 
profession. This need received Parliamentary support and recognition in the form of the Report of 1914 Select Committee on Patent Medicines.

Had its recommendations been implemented promptly drug safety issues may well have been identified much earlier, especially if the recommendations that control of medicines should be a ministerial responsibility, that there was a need for a Medicines Division within the Department of Health, and that all drugs should be approved by a Medicines Commission prior to their registration, had been implemented. A Medicines Division would have been in a much better position to monitor not only drug safety but also quality, had the recommendations that provision should be made for analysis of drugs by the Government Chemist, and that ingredients of preparations should be put on labels, been impelemented; but also efficacy, had the recommendation that inspectors should examine advertisements for drugs been implemented.

In the event implementation of these recommendations would be shelved with the start of the First World War. They were to be implemented at various times over the years that followed, usually in response to incidents of one sort or another. Like The Lancet Commission before it, the report of the 1914 Select Committee on Patent Medicines has been seen as not only a missed opportunity but also a direct cause of subsequent disasters. Mann's statement in 1989 that "it is not altogether fanciful to look on the children of the thalidomide disaster as late and unwitting victims of World War I' has been widely quoted. But this statement too has proved fanciful. Repeated incidents since the Medicines Act of 1968 have demonstrated that neither regulation nor testing are infallible. It seems no more likely that the problem with thalidomide would have been detected if the recommendations of the 1914 Select Committee on Patent Medicines had been implemented than had The Lancet Commission been anything other than the limited exercise that it was.

\section{Conclusions}

So a discussion of the three key events reviewed in this paper suggests that when the wider social, political and economic contexts of medicines regulation is taken into account, it is unrealistic, and indeed unfair, to suppose that any precedents provided opportunities or gave early warning signs that might have resulted in the thalidomide disaster being anticipated or avoided, given the state of knowledge at the time. Things were rarely clear cut; evidence was often more circumstantial than unequivocal; opinions were divided; unregulated progress was rapid. But these three events have similarities are well as differences. Are there any general conclusions about the history of drug safety we can draw from this review and discussion?

The Lancet Commission on chloroform was a product of its time and it is significant in many ways. It exposed medical prevarication resulting from the convergence of elitism, rivalry and 
paternalism. It illustrated the fact that elite opinion trumped evidence, that medical dogma trumped patient safety, and that focusing on one issue often meant losing sight of others. It is concluded that The Lancet Commission was a worthwhile but limited initiative, but that any concept of a more comprehensive drug safety monitoring scheme was not shared at the time. There was never any discussion about extending the review to other drugs, or indeed of continuing it with regard to anaesthetics. The medical profession had no grounds for believing that there was a need for continuing action.

As we have seen, histories of pharmacovigilance commonly describe the Commission's report as the forerunner of spontaneous reporting systems for suspected adverse drug reactions; and they frequently suggest that it was a missed opportunity to introduce a more wide ranging drug safety monitoring scheme. But historians would be wrong to view the Lancet initiative as a missed opportunity, or to view its report as the origin of pharmacovigilance. And a review of the wider picture indicates that it would be unfair to accuse those responsible for The Lancet Commission Report of failing to identify the need for a more comprehensive drug safety monitoring scheme.

The history of drug safety in Great Britain is the history of emerging concern about the control of harmful substances. Their regulation began with a concern about poisons and poisoning, unlike in the United States where the origins of drug regulation lie in adulteration rather than poisoning. ${ }^{71}$ The early regulation of drug supply in Britain has been discussed at length by Holloway. ${ }^{72}$ Before 1851 any substance, no matter how dangerous, could be sold and used without constraint by anyone. The 1851 Arsenic Act represented the first attempt to regulate dangerous substances. This was followed by a series of pharmacy and poisons Acts which gradually extended controls, and medicines continued to be controlled as poisons until the Medicines Act of 1968.

There had been other warnings of shortcomings in the regulation of medicines before thalidomide. In 1952, an article written by Dr George Discombe appeared in the British Medical Journal in which he cited some of the tragedies seen by clinical and forensic pathologists which resulted from drug idiosyncrasies. ${ }^{73}$ He warned about the dangers of the lack of contact between the Poisons Board (prescription medicines were still regulated as poisons at the time) and clinical pathologists concerning the injurious effects of drugs. It was an article which was to be recalled some ten years later as one of the many ignored warnings of inadequate drug testing. ${ }^{74}$ Another significant event often recalled in the light of the tragedy was the publication in 1957 of a report by

\footnotetext{
71 ABRAHAM, J. - Science, Politics and the Pharmaceutical Industry: Controversy and Bias in Drug Regulation . London: Routledge, 1995. p. 45-46.

${ }^{72}$ HOLLOWAY, S.W.F. - 'The Regulation of the Supply of Drugs in Britain Before 1868'. in PORTER, R;TEICH, M. (Eds.) Drugs and Narcotics in History. Cambridge: Cambridge University Press, 1997. p. 77-96.

${ }^{73}$ DISCOMBE, G. - 'Drug Idiosyncrasies'. British Medical Journal. 1 (1952) p. 1270.

${ }^{74}$ HODGES, M.;APPELBE, G.E. - 'Control of the Safety of Drugs 1868-1968, Part2'. The Pharmaceutical Journal. 239 (1987) p. 153.
} 
the World Health Organisation which outlined procedures which, had they been followed, would have avoided much of the tragic consequence of the marketing of thalidomide. ${ }^{75}$

Britain was not alone in identifying precedents which in the light of subsequent events should have been taken more seriously. In the United States authority to enforce the food and drug law of 1906 passed from the Bureau of Chemistry to the Food and Drug Administration in $1927^{76}$ A suggestion for a drug testing scheme had been made at the American Medical Symposium in $1929,{ }^{77}$ and subsequent measures taken included passage of the Food, Drugs and Cosmetics Act in 1938, which made the Food and Drug Administration the gatekeeper to the marketplace to ensure the safety of new drugs. It was the action of one of the Food and Drug Administration's pharmacologist tasked with that responsibility, Frances Kelsey, that subsequently saved the United States from serious exposure to thalidomide. ${ }^{78}$

Post thalidomide, those tasked with re-examining the evidence have reflected on whether warning signs were missed and opportunities ignored. Sir Richard Doll in his review concluded that epidemiologists invariably had to reach conclusions based on incomplete data, but that doubt over the interpretation of epidemiological observations should not be allowed to delay action. ${ }^{79}$

In a debate in Parliament on the control and safety of drugs on 8 May 1963 the minister responsible, Kenneth Robinson, Minister of Health, reflected that 'The House and the public suddenly woke up to the fact that any drug manufacturer could market any product, however inadequately tested, however dangerous, without having to satisfy any independent body as to its efficacy and safety, and the public was almost uniquely unprotected in this respect' ${ }^{80}$ In the same debate Enoch Powell, the Secretary of State for Health, noted that 'Safety... is relative, whatever be the arrangements, whatever be the law...It is relative in the sense that there is no system that can be devised which will make doctors or scientists aware of what medicine and science have not yet suspected'. ${ }^{81}$

In the immediate aftermath of thalidomide drug safety seems to have had more of an impact on the medical than the pharmacy profession. Books on the history of pharmacy in Great Britain appearing in the early 1960s make no mention of it. Whilst Matthews' book in $1962^{82}$ may already have been at the printers at the time of the thalidomide disaster the same would not have been true

\footnotetext{
75 ANONYMOUS. - Technical Report Series No. 138. Geneva: World Health Organisation, 1957.

${ }^{76}$ YOUNG, J.H. - 'Federal Drug and Narcotic Legislation'. Pharmacy in History. 37 (1995) p. 61.

77 APPELBE, G.E. - 'From Arsenic to Thalidomide: A Brief History of Medicine Safety'. In ANDERSON, S. (Ed.) Making Medicines: A Brief History of Pharmacy and Pharmaceuticals. London: The Pharmaceutical Press, 2005. p. 258.

${ }^{78}$ McFADYEN, R.E. - 'Thalidomide in America: A Brush With Tragedy'. Clio Medica. 11:2 (1976) p. 79-93.

${ }^{79}$ DOLL, R. - 'Hazards of the First Nine Months: An Epidemiologist's Nightmare'. Journal of the Irish Medical Association. 66 (1973) p. 117-126.

${ }^{80}$ ROBINSON, K. - Hansard. London: Official Reports of Debates in Parliament. 8 May (1963) col. 456.

${ }^{81}$ POWELL, E. - Hansard. London: Official Reports of Debates in Parliament. 8 May (1963) col. 455.

${ }^{82}$ MATTHEWS L.G. - History of Pharmacy in Britain. Edinburgh: E \& S Livingstone, 1962.
} 
for Trease's chronological account of the history of pharmacy which was published in $1964{ }^{83}$ Poynder's 1965 book on the evolution of pharmacy in Great Britain, based on the proceedings of a conference, also makes no reference to drug safety, ${ }^{84}$ suggesting that by that stage the subject had not been recognised as being of significant historical interest. Neither does thalidomide receive anything other than a cursory mention in the official history of the Royal Pharmaceutical Society. ${ }^{85}$ Only in 2005 did it make an appearance in a textbook on the history of pharmacy in Britain. ${ }^{86}$

If leading actors are rather selective and biased in their interpretation of the past we may wonder whether they were any better at anticipating the future. Sir Derrick Dunlop in his address in 1980 describing the impact of the changes that the thalidomide disaster had triggered, and the wider social and political changes that would be necessary to avoid such incidents in the future, stated: 'It is fairly safe to conclude that by the end of the century social security schemes of one kind or another will be universal in civilised countries, providing medical care for everyone.' Perhaps progress is not always quite as rapid as initial optimism and enthusiasm might indicate.

Artigo Recebido a 30 de outubro de 2015 I Aceite a 06 de março de 2016

\footnotetext{
${ }^{83}$ TREASE G.E. - Pharmacy in History. London: Baillière, Tindall and Cox, 1964.

${ }^{84}$ POYNTER F.N.L. - The Evolution of Pharmacy in Britain. London: Pitman Medical, 1965.

${ }^{85}$ HOLLOWAY, S.W.F. - Royal Pharmaceutical Society of Great Britain 1841 to 1991: A Political and Social History. London: The Pharmaceutical Press, 1991. p. 397.

${ }^{86}$ APPELBE, G.E. - 'From Arsenic to Thalidomide: A Brief History of Medicine Safety'. In ANDERSON, S. (Ed.) Making Medicines: A Brief History of Pharmacy and Pharmaceuticals. London: The Pharmaceutical Press, 2005. p. 243-260.
} 